\title{
EFFECT OF DEFICIT IRRIGATION MANAGEMENT ON QUALITATIVE AND QUANTITATIVE YIELD OF SUGAR BEET (BETA VULGARIS L.) IN KARAJ, IRAN
}

\author{
MANSURI, M. ${ }^{1}-$ BABAZADEH, $.^{1 *}-$ EMdAD, M. R. ${ }^{2}-$ TALEGHANI, D. ${ }^{3}$ \\ ${ }^{I}$ Department of Water Science and Engineering, Science and Research Branch, Islamic Azad \\ University, Tehran, Iran \\ ${ }^{2}$ Department of Irrigation and Soil Physics, Soil and Water Research Institute, Agricultural \\ Research, Education and Extension Organization (AREEO), Karaj, Iran \\ ${ }^{3}$ Sugar Beet Seed Institute, Agricultural Research, Education and Extension Organization \\ (AREEO), Karaj, Iran \\ *Corresponding author \\ e-mail: h_babazadeh@hotmail.com; phone: +98-912-699-0105 \\ (Received 23 ${ }^{\text {rd }}$ Aug 2017; accepted 21 ${ }^{\text {st }}$ Nov 2017)
}

\begin{abstract}
Environmental pollution and food security resulting from agricultural input surpluses are of great concern to the world in recent year. Improving use efficiency of agricultural inputs becomes an important way to relieve above issues. Due to the long growing season of sugar beet, its response to deficit irrigation is very important. According to the objective, a field study was conducted to investigate the effects of conventional (control), fixed and alternate furrow irrigation on qualitative and quantitative yields of sugar beet was carried out in Karaj, Iran. The treatments were applied in two consecutive years (2013 and 2014) as randomized complete block design with three replications. The irrigation water applied in the control treatment was $1127 \mathrm{~mm}$, while the fixed and alternate furrow irrigation reduced drainage by $44 \%$ and $50 \%$, respectively. The root yield was obtained $79 \mathrm{t} / \mathrm{ha}$ under alternate furrow irrigation, and $16 \%$ higher compared to fixed furrow irrigation. Average water use efficiency (WUE) for sugar beet root production in conventional, fixed, and alternate furrow irrigation were achieved 7, 11, and $12 \mathrm{~kg} / \mathrm{m}^{3}$, respectively. Moreover, the maximum water use efficiency for of pure sugar production $(1.5$ $\mathrm{kg} / \mathrm{m}^{3}$ of water used) was obtained in the alternate furrow irrigation treatment. So, it was 23 and $117 \%$ higher than fixed and conventional furrow irrigation treatments, respectively. $\alpha$-amino nitrogen absorption in the alternate furrow irrigation treatment increased by $29 \%$ compared to other treatments, which suggest balanced fertilization management is needed in alternate furrow irrigation. Consequently, alternate furrow irrigation management with reduced drainage achieved maximum WUE.
\end{abstract}

Keywords: alternate furrow irrigation, fix furrow irrigation, water use efficiency, root yield, drainage

\section{Introduction}

Agricultural input surpluses cause severe environmental pollution and natural resource depletion; thus, the need to improve the utilization efficiency of agricultural inputs has become urgent. However, the high crop production in this region mainly depends on the surplus of agricultural inputs, which has caused serious resource shortage, environmental pollution and soil erosion in recent years (Liang et al., 2010).

Water resource is an important factor influencing crop productivity (Hardin, 2008). Crop production in semi-arid area mainly relies on irrigation. This is true for Iran where annual rainfall is less than $400 \mathrm{~mm}$ with negligible amount of rain during the growing season of summer crops (Sepaskhah and Parand, 2006). Drought stress is one of the main problems in the crop production in arid and semi arid area, and it is a serious threat to successful crop production all over the world (Ober, 2001). Akhavan et al. 
(2007), demonstrated that, deficit irrigation, if correctly managed, can be one of the known strategies for making optimal use of water. Increased water use efficiency (WUE) in agriculture plays an important role for maintaining food security and, it is one of the important goals in water use management (Deng et al., 2006). Therefore, to maintain grain supplement stably and safely, it is critical to improve the utilization efficiency of agricultural inputs, save resource consumption and ensure food security (Wang et al., 2016).

Thus, new irrigation strategies must be established to use the limited water resource more efficiently. One of the new irrigation strategies is the deficit irrigation scheduling, which is a valuable and sustainable production strategy for dry region (Greets and Raes, 2009). Under good management practices, deficit irrigation can result in substantial water saving with little impact on the quality and quantity of the harvested yield (Topak et al., 2011). In general, it has been proved that under stress conditions concentrations of dissolved substances increase to correct the conditions, and that this is directly related to the physiological system of the plants and osmotic absorption by the roots (Morillo-Velarde and Ober, 2006). Some field crops including sugar beet can adapt well to deficit irrigation practices (Kirda et al., 2002). Sugar beet is reputed to be a deep rooting crop and relatively insensitive to water stress because of the morphological and physiological characteristics of its root system (Doorenbosand and Kasam, 1979). Sugar beet has the ability to grow in a wide range of salinities and climatic conditions (Tognetti et al., 2003), and Sugar beet is resistant to drought and needs strategies to reduce the effects of drought stress so that it can achieve high yields (Hsiao, 2000). Sepaskhah (1996) reported that, for plants like sugar beet (grown for their leaves or roots) shallow groundwater and alternate furrow irrigation led to high WUE, but deep groundwater might cause substantial reduction in root yield if deficit irrigation was applied. One of the internal responses of sugar beet to water shortage, in addition to reduced growth, is increased sugar concentration in roots. On other hand Uçan and Gençoğlan (2004), reported that the root yield increased as the applied irrigation water increased, and a linear relationship was found between these two parameters. However, drought stress is an important factor in reducing yield which, depending on the climate under which it is grown, varies from 5 to 15 t/ha (Pidgeon et al., 2001).

In the several growth stages of sugar beet, many researchers have investigated deficit irrigation management. Firoozabadi et al. (2003) reported that they applied mild, moderate, and severe stress continuously on sugar beet under normal conditions during the growing season, and achieved 58, 45, and $34 \mathrm{t} /$ ha root yields, respectively. Bazza and Tayaa (1999) have reported that deficit irrigation by $25 \%$ in furrow irrigation led to $21 \%$ reduction in root yield, but that water use efficiency would increase by $5 \%$ compared to the control that received full irrigation. In the study carried out by Rytter (2005), it has been reported that deficit irrigation by $40 \%$ reduced sugar beet dry matter by $50 \%$ compared to the treatment that received full irrigation. Applying drought stress in the last growing season increased root impurities, especially nitrogen, sodium, potassium, and hence, increased molasses production. Therefore, water stress in the end period of sugar beet season has an effect on sugar concentration of the harvested crop (Clover et al., 2001). Topak et al. (2011) studied the effect of deficit irrigation on sugar beet in semi-arid zone by drip irrigation system, and concluded that $25 \%$ and $50 \%$ saving in irrigation water caused 6.1 and $45.7 \%$ reduction, respectively, in the net income. Albayrak et al. (2010) reported that total sugar yield in alternate furrow irrigation increased compared to conventional furrow irrigation and water use efficiency 
was 29\% higher. Mohamoodi et al. (2008) studied the relation to different irrigation regimes in 30, 50, 70 and 90\% FC. Irrigation treatment showed that the optimum soil water content for root yield is at $70 \%$ field capacity with $78.5 \mathrm{t} / \mathrm{ha}$ and maximum quality observed. In a research carried out by Hassanli et al. (2010) it was shown that drip irrigation water management could lead to production of up to $79 \mathrm{t} / \mathrm{ha}$ of sugar beet roots, with water use efficiency in root and sugar production being 9 and $1.26 \mathrm{~kg} / \mathrm{m}^{3}$, respectively.

Because of water scarcity in the study area sugar beet cultivation relies extensively on irrigation and is mainly irrigated using conventional furrow systems without soil moisture monitoring or climate based scheduling. Consequently water stress is a common cause of yield loss. Therefore alternative irrigation technologies and more efficient irrigation management should be developed to overcome the problems associated with water stress or over irrigation (Hassanli et al., 2010).

Under these conditions, there is one way for farmers to maximize their profit on sugar beet production. Research results show that the best management of deficit irrigation on sugar beet crop and to choose the most appropriate irrigation scheduling for saving irrigation water is AFI (Topak et al., 2011), therefore deficit irrigation management, the optimum irrigation scheduling for the sugar beet in the arid and semiarid region.

The objectives of this study were to evaluate the effect of deficit irrigation management on quality and quantity yield of sugar beet. The study examined reduce drainage, yields and IWUE for different irrigation management.

\section{Material and methods}

Field experiments of furrow irrigated sugar beet were conducted at the research field of the Kamalabad station of the Sugar Beet Research Institute in Karaj, Iran, at $50^{\circ} 55^{\prime}$ E, longitude, $35^{\circ} 55^{\prime} \mathrm{N}$ latitude and $1313 \mathrm{~m}$ altitude during 2013 and 2014 growing season of sugar beet. Climate in this region is semi-arid with total annual precipitation of $265 \mathrm{~mm}$. In the growing season of sugar beet we have no significant rainfall in both years. The soil in this area have no salinity and drainage problems such as water table, some physical properties of the experimental field soil are presents in Table 1, and some chemical irrigated water quality properties are shown in Table 2.

The experiments were conducted in the same field for the 2-year period. The cultivar, fertilizing, and insect control in all plots were the same for the 2 years. The Pars sugar beet variety was planted on 27 April 2013 and on 2 May 2014, and harvest day were 15 November and 27 October, respectively, for 2013 and 2014. The experimental design was a randomized block with three replications. Each plot consists of 12 row of sugar beet that was $90 \mathrm{~m}$ long and $0.5 \mathrm{~m}$ wide, the slope of furrow was about $0.00019 \mathrm{~m} \mathrm{~m}^{-1}$. Sowing density was 3-6 plants per meter.

The design consisted of three irrigation methods. The irrigation methods were alternate furrow irrigation (AFI), fixed furrow irrigation (FFI) and conventional furrow irrigation (CFI). AFI is a deficit irrigation management which one of the two neighboring furrows is alternately irrigated during consecutive watering. The second deficit irrigation is FFI that irrigation is fixed to one of the two neighboring furrows and at last CFI is the conventional method where all furrows irrigated per irrigation, contrast to above mentioned managements. 
Table 1. Some Physical properties of experimental field soil

\begin{tabular}{c|c|c|c|c|c|c|c}
\hline $\begin{array}{c}\text { Depth } \\
\text { cm }\end{array}$ & $\begin{array}{c}\text { Clay } \\
\boldsymbol{\%}\end{array}$ & $\begin{array}{c}\text { Silt } \\
\boldsymbol{\%}\end{array}$ & $\begin{array}{c}\text { Sand } \\
\boldsymbol{\%}\end{array}$ & Texture & $\begin{array}{c}\text { Bulk density } \\
\text { gr/cm }\end{array}$ & $\begin{array}{c}\text { Field capacity } \\
\mathbf{\%}\end{array}$ & $\begin{array}{c}\text { Permanent wilting } \\
\text { point \% }\end{array}$ \\
\hline $0-30$ & 31.4 & 42 & 26.6 & Clay loam & 1.47 & 27.4 & 14 \\
$30-60$ & 34.6 & 27.4 & 38 & Clay loam & 1.42 & 26.6 & 14.9 \\
\hline
\end{tabular}

Table 2. Chemical properties of irrigation water at the study area

\begin{tabular}{c|c|c|c|c|c|c|c|c|c}
\hline $\mathbf{H C O}_{\mathbf{3}}(\mathbf{m g} / \mathbf{l})$ & $\mathbf{C O}_{\mathbf{3}}(\mathbf{m g} / \mathbf{l})$ & $\mathbf{C l}(\mathbf{m g} / \mathbf{l})$ & $\mathbf{K}(\mathbf{m g} / \mathbf{l})$ & $\mathbf{N a}(\mathbf{m g} / \mathbf{l})$ & $\mathbf{M g}(\mathbf{m g} / \mathbf{l})$ & $\mathbf{C a}(\mathbf{m g} / \mathbf{l})$ & $\mathbf{E C}(\mathbf{d S} / \mathbf{m})$ & $\mathbf{S A R}$ & $\mathbf{p H}$ \\
\hline 146 & 0 & 0.8 & 0.8 & 62 & 16 & 23 & 0.5 & 2.2 & 8 \\
\hline
\end{tabular}

Soil water content was measured by gravimetric method in all plots. Irrigation was applied at different intervals according to the soil water content measurement in the root zone. All plot irrigated when the soil water content in the root zone reached $50 \%$ of available soil moisture. Doorenbos and Kassam (1979) indicated that the maximum sugar beet yield was usually obtained when the sugar beet plants were irrigated at $50 \%$ of available water holding capacity.

The required volume of water was calculated using Equation 1:

$$
d_{n}=\Sigma\left(\theta f c_{i}-\theta_{i}\right) \Delta z
$$

where $D_{n}$ is the net volume of irrigation water in mm, $\theta_{\text {fci }}$ plant moisture content at field capacity (in volumetric percentage), and $\theta_{\mathrm{i}}$ soil moisture prior to each irrigation (in volumetric percentage), and $\Delta \mathrm{z}$ soil depth in $\mathrm{mm}$. Therefore, the volume of irrigation water was determined beforehand based on soil moisture.

Siphon tubes (25 mm, ID) from an equalizing ditch supplied the water for irrigation treatment. The amount of irrigated water was measured by volumetric methods, and that runoff discharge of the furrows measured by WSC flume (Type II).

The crop evapotranspiration during each irrigation interval (ET, $\mathrm{mm}$ ) was estimated from Equation 2 (Heerman, 1985):

$$
E T=I+R-D \pm \Delta W
$$

where ET is the evapotranspiration $(\mathrm{mm}), \mathrm{I}$ is the depth of irrigation $(\mathrm{mm}), \mathrm{R}$ is the rainfall $(\mathrm{mm}), \mathrm{D}$ is the depth of drainage $(\mathrm{mm})$, and $\Delta \mathrm{W}$ is the change of soil water storage in the measured soil depth. In this study, $\mathrm{R}$ was observed at the climatology station in Karaj. The amount of irrigation water applied was checked by inflow and outflow from furrow. $\Delta \mathrm{W}$ was obtained from the difference between soil water content values to a depth of $0.6 \mathrm{~m}$. The value of $\mathrm{D}$ was assumed to be negligible because the amount of irrigation water not increased above field capacity as result of deficit irrigation.

Sugar beet root yield was determined by machine harvesting the five center rows in each plot (each $8 \mathrm{~m}$ long). The quality parameters in roots were analyzed in the laboratory of Sugar Beet Research Institute in Karaj, Iran.

Considering the volume of water used and crop yield, water efficiency index was calculated using Equation 3: 


$$
I W U E=\frac{Y}{W}
$$

where IWUE is irrigation water use efficiency $\left(\mathrm{kg}\right.$ produced $\mathrm{root} / \mathrm{m}^{3}$ irrigation water used), Y root or sugar yield ( $\mathrm{kg} / \mathrm{ha})$, and $\mathrm{W}$ the volume of water used $\left(\mathrm{m}^{3} / \mathrm{ha}\right)$.

Analysis of variance was conducted to evaluate the effects of the treatments on sugar beet root yield ( $\mathrm{t} / \mathrm{ha}$ ), white sugar yield (t/ha) and quality parameters, Duncan's multiple range tests was used to compare and rank the treatment means. Differences were declared significant at $P<0.05$ or $P<0.01$.

\section{Results}

ANOVA of applied water, root yield and sugar yield showed in Table 3. ANOVA of the combined 2-year sugar beet root data and Year indicated significant effects for irrigation management. Irrigation management interaction was significant in sugar beet root yield but not significant in white sugar yield (Table 3).

Table 3. ANOVA of irrigation and yield of sugar beet

\begin{tabular}{c|c|c|c|c|c|c}
\hline & & df & Sum of squares & MS & F-value & Sig. \\
\hline \multirow{4}{*}{ Root yield } & Year (Y) & 1 & 98.07 & 98.07 & 19.68 & 0.0022 \\
& Treatment (T) & 2 & 771.59 & 385.79 & 77.41 & $<0.0001$ \\
& $\mathrm{Y} * \mathrm{~T}$ & 2 & 138.07 & 69.03 & 13.85 & 0.0025 \\
\hline \multirow{3}{*}{ Sugar yield } & Year (Y) & 1 & 54.60 & 54.60 & 155.65 & $<0.0001$ \\
& Treatment (T) & 2 & 22.19 & 11.09 & 31.63 & 0.0002 \\
& $\mathrm{Y} * \mathrm{~T}$ & 2 & 0.55 & 0.27 & 0.78 & 0.4901 \\
\hline \multirow{3}{*}{ WUE $_{\mathrm{r}}$} & Year (Y) & 1 & 0.0008 & 0.0008 & 0.01 & 0.9401 \\
& Treatment (T) & 2 & 87.96 & 43.98 & 330.59 & $<0.0001$ \\
& $\mathrm{Y} * \mathrm{~T}$ & 2 & 11.29 & 5.66 & 42.43 & $<0.0001$ \\
\hline \multirow{3}{*}{ WUE $_{\mathrm{s}}$} & Year (Y) & 1 & 0.69 & 0.69 & 94.12 & $<0.0001$ \\
& Treatment (T) & 2 & 2.19 & 1.09 & 149.09 & $<0.0001$ \\
& $\mathrm{Y} * \mathrm{~T}$ & 2 & 0.07 & 0.04 & 4.76 & 0.0435 \\
\hline
\end{tabular}

The effect of year on white sugar yield were significant, and the result of Duncan's multiple range test showed significant differences $(p<0.01)$ among some treatments in white sugar yield for the combined 2 year (Table 3). White sugar yield with AFI was always higher than at other full and deficit irrigation management.

The number of irrigation events and amount of applied water, fresh root and white sugar yield values of sugar beet for each irrigation management are shown in Table 4. The seasonal amount of applied water was the mean of the two seasonal and amounted to $1127 \mathrm{~mm}, 599 \mathrm{~mm}$ and $625 \mathrm{~mm}$ for CFI, FFI and AFI, respectively. 
Table 4. Total number of irrigation, amounts of irrigation and yield of sugar beet

\begin{tabular}{|c|c|c|c|c|c|c|c|c|}
\hline$\stackrel{\grave{\varpi}}{\grave{\nu}}$ & 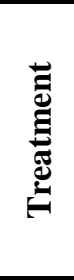 & 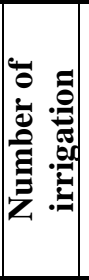 & 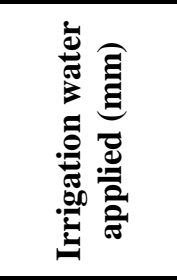 & 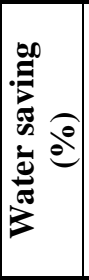 & 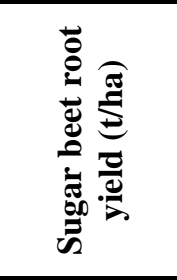 & 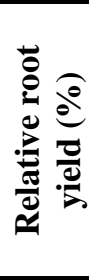 & 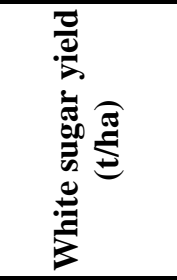 & 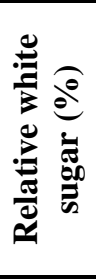 \\
\hline \multirow{3}{*}{2013} & CFI & 13 & $1197 \pm 6.81^{\mathrm{a}}$ & $0^{\mathrm{a}}$ & $83.6 \pm 1.42^{\mathrm{a}}$ & $100^{\mathrm{a}}$ & $10.1 \pm 0.76^{\mathrm{b}}$ & $100^{\mathrm{b}}$ \\
\hline & FFI & 13 & $597 \pm 8.74^{\mathrm{e}}$ & $44^{\mathrm{b}}$ & $74.5 \pm 1.58^{\mathrm{c}}$ & $89^{c}$ & $8.8 \pm 0.69^{c}$ & $87^{\mathrm{b}}$ \\
\hline & AFI & 13 & $667 \pm 6.03^{c}$ & $56^{\mathrm{b}}$ & $80.6 \pm 0.78^{\mathrm{ab}}$ & $96^{\mathrm{b}}$ & $12 \pm 0.89^{\mathrm{a}}$ & $118^{\mathrm{a}}$ \\
\hline \multirow{3}{*}{2014} & CFI & 11 & $1058 \pm 4.51^{b}$ & $0^{\mathrm{b}}$ & $84.7 \pm 3.82^{\mathrm{a}}$ & $100^{\mathrm{a}}$ & $6.6 \pm 0.41^{\mathrm{d}}$ & $100^{\mathrm{b}}$ \\
\hline & FFI & 11 & $602 \pm 2.00^{\mathrm{d}}$ & $43^{\mathrm{b}}$ & $62.4 \pm 1.00^{\mathrm{d}}$ & $73^{\mathrm{b}}$ & $5.8 \pm 0.18^{\mathrm{d}}$ & $88^{\mathrm{b}}$ \\
\hline & AFI & 11 & $584 \pm 2.00^{\mathrm{e}}$ & $45^{\mathrm{b}}$ & $77.8 \pm 4.77^{\mathrm{bc}}$ & $92^{\mathrm{c}}$ & $8.1 \pm 0.68^{c}$ & $124^{\mathrm{a}}$ \\
\hline Year $(\mathrm{Y})$ & & & $* *$ & & $* *$ & & $* *$ & \\
\hline Tretment (T) & & & $* *$ & & $* *$ & & $* *$ & \\
\hline $\mathrm{Y} * \mathrm{~T}$ & & & $* *$ & & $* *$ & & Ns & \\
\hline
\end{tabular}

$*$ significant in $5 \%$ level, $* *$ significant in $1 \%$ level, ns non-significant

Table 5 shows the WUEr and WUEs for two years and average of the both years. WUE was significant $(\mathrm{p}<0.01)$. The WUEr for CFI, FFI and AFI was 7.49, 11.42 and $12.70 \mathrm{~kg} / \mathrm{m}^{3}$ respectively and WUEs for CFI, FFI and AFI was $0.73,1.21$ and 1.59 $\mathrm{kg} / \mathrm{m}^{3}$ respectively.

Table 5. Water use efficiency values of root and sugar yield in combined year

\begin{tabular}{c|c|c|c|c|c|c}
\hline \multirow{2}{*}{ Treatment } & \multicolumn{3}{|c|}{ WUE $_{\mathbf{r}} \mathbf{( K g / \mathbf { m } ^ { 3 } )}$} & \multicolumn{3}{c}{ WUE $_{\mathbf{s}}\left(\mathbf{K g} / \mathbf{m}^{\mathbf{3})}\right.$} \\
\cline { 2 - 7 } & $\mathbf{2 0 1 3}$ & $\mathbf{2 0 1 4}$ & Average of year & $\mathbf{2 0 1 3}$ & $\mathbf{2 0 1 4}$ & Average of year \\
\hline CFI & $6.98 \pm 0.08^{\mathrm{b}}$ & $8.01 \pm 0.35^{\mathrm{a}}$ & $7.49 \pm 0.59^{\mathrm{a}}$ & $0.84 \pm 0.06^{\mathrm{b}}$ & $0.62 \pm 0.04^{\mathrm{b}}$ & $73 \pm 0.13^{\mathrm{b}}$ \\
FFI & $12.48 \pm 0.44^{\mathrm{b}}$ & $10.36 \pm 0.19^{\mathrm{b}}$ & $11.42 \pm 1.27^{\mathrm{b}}$ & $1.47 \pm 0.10^{\mathrm{a}}$ & $0.96 \pm 0.03^{\mathrm{a}}$ & $1.21 \pm 0.30^{\mathrm{a}}$ \\
AFI & $12.08 \pm 0.19^{\mathrm{b}}$ & $13.32 \pm 0.80^{\mathrm{b}}$ & $12.70 \pm 0.84^{\mathrm{b}}$ & $1.79 \pm 0.14^{\mathrm{a}}$ & $1.38 \pm 0.11^{\mathrm{a}}$ & $1.59 \pm 0.25^{\mathrm{a}}$ \\
\hline
\end{tabular}

WUEr: Water use efficiency of root yield

WUEs: Water use efficiency of sugar yield

ANOVA of the combined 2-year show that, irrigation management were not significant in polarization, white sugar content and molasses. Alkalinity, Sodium, Potassium and amino nitrogen was affected by irrigation management and year. Organic material such as amino nitrogen, potassium and sodium was affected by irrigation management. Molasses was not significant in irrigation management (Table 6).

Sugar beet root quality data in relation to different irrigation managements are presented in Table 7.

Figure 1 shows the relationships between root yield and applied water under different irrigation managements. Regression analysis showed that there was a polynomial relationship between seasonal water consumption and sugar beet yield, which is a good function and significant (Figure 2). 
Table 6. ANOVA of sugar beet root quality parameters under different irrigation management

\begin{tabular}{c|c|c|c|c|c|c}
\hline & & $\boldsymbol{d} \boldsymbol{f}$ & Sum of squares & $\boldsymbol{M S}$ & $\boldsymbol{F}$-value & Sig. \\
\hline \multirow{4}{*}{ Polarization } & Year (Y) & 1 & 31.90 & 31.90 & 30.12 & 0.0006 \\
& Treatment (T) & 2 & 26.74 & 13.37 & 12.64 & 0.0033 \\
& $\mathrm{Y} * \mathrm{~T}$ & 2 & 2.25 & 1.13 & 1.07 & 0.39 \\
\hline \multirow{5}{*}{ Sodium } & Year (Y) & 1 & 33.4 & 33.4 & 191.80 & $<0.0001$ \\
& Treatment (T) & 2 & 1.87 & 0.93 & 5.36 & 0.03 \\
& $\mathrm{Y} * \mathrm{~T}$ & 2 & 4.43 & 2.21 & 12.71 & 0.003 \\
\hline \multirow{5}{*}{ Potassium } & Year (Y) & 1 & 1.12 & 1.12 & 10.68 & 0.0114 \\
& Treatment (T) & 2 & 1.039 & 0.52 & 5.02 & 0.0387 \\
& $\mathrm{Y} * \mathrm{~T}$ & 2 & 1.10 & 0.55 & 5.32 & 0.0340 \\
\hline \multirow{5}{*}{ Alkalinity Nitrogen } & Year (Y) & 1 & 2.20 & 2.019 & 134.52 & $<0.0001$ \\
& Treatment (T) & 2 & 0.44 & 0.219 & 14.63 & 0.0021 \\
& $\mathrm{Y} * \mathrm{~T}$ & 2 & 0.36 & 0.181 & 12.09 & 0.0038 \\
\hline & Year (Y) & 1 & 234.07 & 234.07 & 392.98 & $<0.0001$ \\
& Treatment (T) & 2 & 14.91 & 7.46 & 12.52 & 0.0034 \\
& $\mathrm{Y} * \mathrm{~T}$ & 2 & 5.90 & 2.95 & 4.95 & 0.0398 \\
\hline \multirow{5}{*}{ Molasses } & Year (Y) & 1 & 5.42 & 5.42 & 77.11 & $<0.0001$ \\
& Treatment (T) & 2 & 0.30 & 0.15 & 2.14 & 0.1800 \\
& $\mathrm{Y} * \mathrm{~T}$ & 2 & 0.19 & 0.09 & 1.32 & 0.3204 \\
\hline
\end{tabular}

Table 7. Sugar beet root quality parameters under different irrigation management

\begin{tabular}{|c|c|c|c|c|c|c|c|c|}
\hline 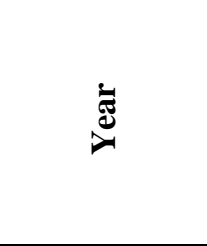 & 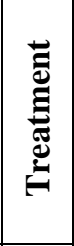 & 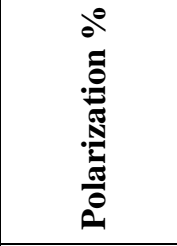 & 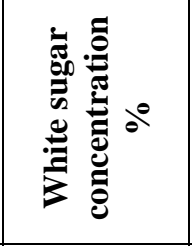 & 恶 & 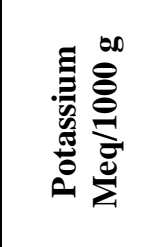 & 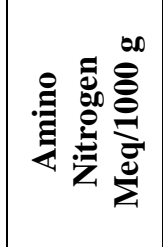 & 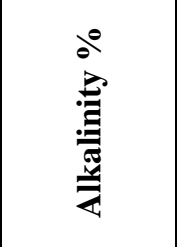 & $\begin{array}{l}0 \\
y \\
0 \\
0 \\
\frac{5}{0} \\
\frac{\sigma}{0}\end{array}$ \\
\hline \multirow{3}{*}{2013} & CFI & $14.6 \pm 0.87^{b}$ & $11.8 \pm 0.87^{\mathrm{bc}}$ & $1.7 \pm 0.34^{\mathrm{d}}$ & $4.4 \pm 0.12^{\mathrm{bc}}$ & $1.3 \pm 0.03^{\mathrm{b}}$ & $4.8 \pm 0.18^{c}$ & $1.9 \pm 0.11^{\mathrm{b}}$ \\
\hline & FFI & $14.4 \pm 1.11^{\mathrm{b}}$ & $12.1 \pm 1.04^{\mathrm{b}}$ & $2.2 \pm 0.39^{\mathrm{d}}$ & $4.0 \pm 0.51^{\mathrm{c}}$ & $1.3 \pm 0.12^{\mathrm{b}}$ & $4.9 \pm 0.56^{\mathrm{c}}$ & $1.9 \pm 0.32^{b}$ \\
\hline & AFI & $17.6 \pm 0.95^{\mathrm{a}}$ & $14.8 \pm 0.97^{\mathrm{a}}$ & $1.7 \pm 0.35^{\mathrm{d}}$ & $5.0 \pm 0.17^{\mathrm{b}}$ & $1.9 \pm 0.09^{\mathrm{a}}$ & $3.5 \pm 0.20^{\mathrm{c}}$ & $2.2 \pm 0.14^{b}$ \\
\hline \multirow{3}{*}{2014} & $\overline{\mathrm{CFI}}$ & $11.7 \pm 0.63^{\mathrm{c}}$ & $7.8 \pm 0.84^{\mathrm{e}}$ & $5.6 \pm 0.54^{\mathrm{a}}$ & $4.6 \pm 0.19^{\mathrm{bc}}$ & $0.8 \pm 0.05^{\mathrm{c}}$ & $13.6 \pm 1.52^{\mathrm{a}}$ & $3.3 \pm 0.20^{\mathrm{a}}$ \\
\hline & FFI & $12.7 \pm 0.13^{\mathrm{bc}}$ & $9.3 \pm 0.20^{\mathrm{de}}$ & $3.7 \pm 0.39^{c}$ & $5.2 \pm 0.26^{\mathrm{a}}$ & $0.8 \pm 0.12^{\mathrm{c}}$ & $10.9 \pm 1.37^{b}$ & $2.8 \pm 0.09^{\mathrm{a}}$ \\
\hline & AFI & $14.2 \pm 1.50^{\mathrm{b}}$ & $10.4 \pm 1.01^{\mathrm{cd}}$ & $4.5 \pm 0.35^{\mathrm{b}}$ & $5.1 \pm 0.60^{\mathrm{a}}$ & $0.8 \pm 0.21^{\mathrm{c}}$ & $10.5 \pm 1.69^{b}$ & $3.2 \pm 0.58^{\mathrm{a}}$ \\
\hline Year (Y) & & $* *$ & $* *$ & $* *$ & $*$ & $* *$ & $* *$ & $* *$ \\
\hline Treatment $(\mathrm{T})$ & & $* *$ & $* *$ & $*$ & $*$ & $* *$ & $* *$ & Ns \\
\hline $\mathrm{Y}^{* \mathrm{~T}}$ & & Ns & Ns & $* *$ & $*$ & $* *$ & Ns & Ns \\
\hline
\end{tabular}

*significant in $5 \%$ level, ** significant in $1 \%$ level, ns non-significant 


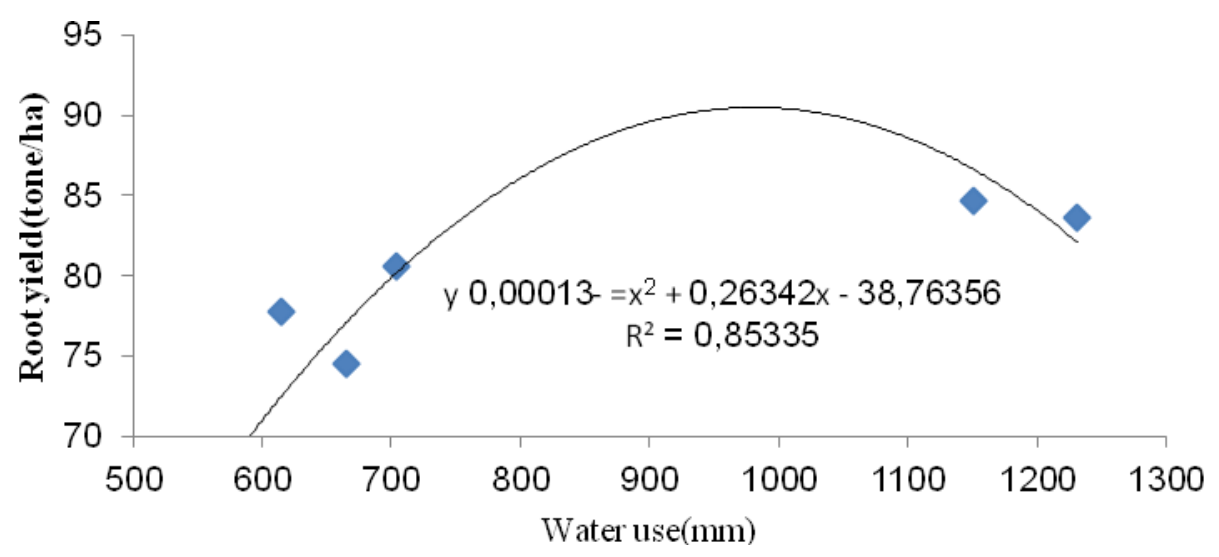

Figure 1. Total root yield of sugar beet as a function of water management

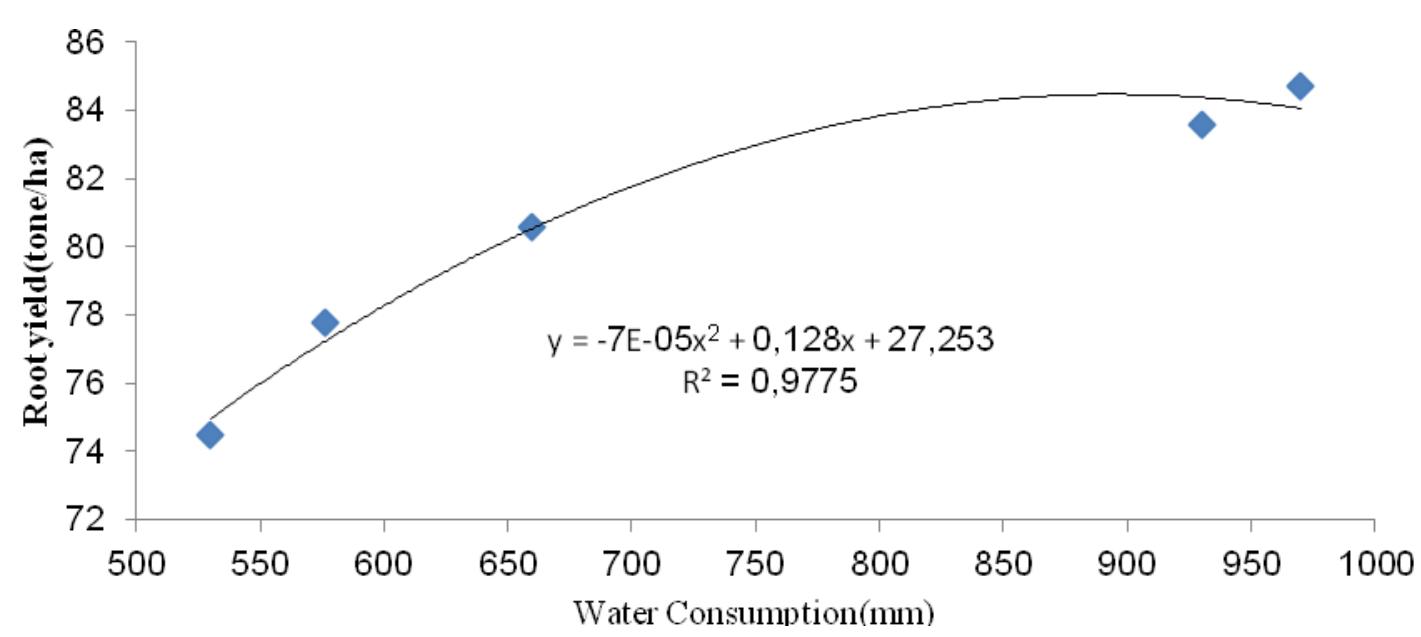

Figure 2. Total root yield of sugar beet as a function of water management

\section{Discussion}

In this research, results show that AFI and FFI saved water by approximately $50.5 \%$ and $43.5 \%$, respectively, as compared to CFI. The lowest amount of applied water under AFI treatments as compared with CFI might be due to the great reduction of wetted surface in AFI; almost half of the soil surface is wetted in AFI as compared with CFI. The highest Eta occurred in the CFI obviously owing to an adequate soil water supply during the growing season $(970 \mathrm{~mm})$. This result supports the outcome obtained by Geraterol et al. (1993), who found that AFI methods can supply water in a way that greatly reduces the amount of wetted surface, with leads to less evapotranspiration and less deep precipitation. Reduced irrigation water due to the alternate furrow management reported by El-Sharkawy et al. (2006), Sepaskhah and Ghasemi (2008), Shayannejad and Moharreri (2009), Ibrahim and Emara (2010) for sugar beet; Nelson and Kaisi (2011).

AFI management, by reducing outlet drainage, can avoid the reduction of groundwater level and deep earth subsidence. AFI management, because of lateral infiltration water in furrow among watering, can cause decreased vertical infiltration. For this reason, nitrate and phosphate that is concentrated in land surface do not move 
into ground water therefore environmental pollution is avoided. AFI management is a good way to reach sustainable agriculture.

Large yield, averaging $84.2 \mathrm{t} / \mathrm{ha}$, was obtained from CFI management plots. Minimum yield was obtained from FFI management plot which averaged $68.5 \mathrm{t} / \mathrm{ha}$. As mentioned by Uçan and Gençoğlan (2004), sugar beet is a crop, which is affected by water deficit. Fluctuation in the yield showed itself to be related to the amount of water given. While the water saving in our study was $44 \%$ (AFI) and $50 \%$ (FFI), the decreases in average beer root yield for 2 years were found to be 6 and $21 \%$, respectively. Therefore, it was observed that the ratio of decreases in beet root yield for each percent deficit rate was not constant. Vamerali et al. (2009) indicated that sugar beet root yields for full and deficit irrigation plots were significantly different. While the rates of decreases in evapotranspiration by Uçan and Gençoğlan (2004), were found as 46.5 and $34 \%$, respectively, the rate of decrease in yield were found as 31.5 and $44 \%$, respectively.

According to these values, it is obvious that there is a parallel relation between the WUEr and WUEs values. Although CFI management that gave the highest root yield and water applied also gave the lowest value of WUEr and WUEs, and the highest value of WUEr and WUEs was obtained in AFI management. This trend supports Febrio et al. (2003), who pointed out that maximum WUE tends to not occur at maximum water applied for sugar beet and usually occurs at an evapotranspiration less than the maximum.

Generally, WUE are influenced by crop yield potential, method of irrigation, method used to estimate or measure water apply and climate characteristics of region.

Root sugar content was generally increased in response to deficit irrigation treatment. Sugar beet roots accumulated more sugar (33\%) under AFI management than under CFI management. Sucrose production from sugar beet depends on maximizing storage root growth over along growing season (Topak et al., 2011). It is necessary to apply a suitable irrigation program together with appropriate agricultural measures for taking a high sugar rate in the sugar beet production (Uçan and Gençoğlan, 2004). Dunham (1993) reported that the increase in the sucrose rate to fresh weight root is due to a slower accumulation of water.

The amount of $\mathrm{K}$ in sugar beet root generally did not change with the water deficit management during both growing seasons in this study.

The effect of deficit irrigation on $\mathrm{Na}$ content of root was significant $(\mathrm{p}<0.05)$ in year 2013 and not significant in year 2014. Ober et al. (2005) reported that the effected of water deficit on Na content is less clear and varies from year to year. Na value range from $1.7 \mathrm{Meq} / 1000 \mathrm{~g}$ for CFI to $2.7 \mathrm{Meq} / 1000 \mathrm{~g}$ in year 2013 and $3.6 \mathrm{Meq} / 1000 \mathrm{~g}$ to 4.5 Meq/1000 g in year 2014. Maralian et al. (2008) demonstrated that, deficit irrigation increased $\mathrm{Na}$ content of root.

The effect of deficit irrigation management on amino $\mathrm{N}$ was not consistent throughout the years. Average amino $\mathrm{N}$ value varied from $1.05 \mathrm{Meq} / 1000 \mathrm{~g}$ to 1.35 $\mathrm{Meq} / 1000 \mathrm{~g}$. The most severe effect of water deficit on amino $\mathrm{N}$ content was observed in AFI management. However, CFI and FFI management had same effect on amino N content of root in both years. It must be noted that these substances reduce sugar beet quality because they are considered non-compatible dissolved materials contrary to nontoxic or compatible dissolved substances such as some amino acids and non-reducing that can accumulate in large amounts without causing any disturbances in the biological functions of cells (Rontein et al., 2002). 
Finally, the result shows that AFI management with reduced water use and environmental pollution can help achieve sustainable agriculture.

\section{Conclusions}

Results showed that deficit irrigation management at sugar beet led to decrease in root and sugar yields. Water use efficiency values increased slightly with increase in water deficit. Water was used more efficiently at the AFI management. Irrigation management AFI could be used for sugar beet grown in arid and semi-arid regions where irrigation water supplies are limited. Under this condition, $44 \%$ of water saving was obtained even though there was a $6 \%$ yield loss for sugar beet, based on the average of 2 years. The alternate furrow irrigation management had the maximum water use efficiency of root and sugar, $12.70 \mathrm{~kg} / \mathrm{m}^{3}$ and $1.59 \mathrm{~kg} / \mathrm{m}^{3}$, respectively.

In conclusion, this study revealed that if water is limited and deficit irrigation is spread over growth season of the sugar beet, $\mathrm{WUE}_{\mathrm{r}}$ and $\mathrm{WUE}_{\mathrm{s}}$ may be improved under 44 and 50\% deficit irrigation schedule. Alternate furrow irrigation management in sugar beet may be feasible for water saving and reducing drainage. It can be concluded that using deficit irrigation is a good water management technique to protect the environment without reducing the water use efficiency.

The current study has been done in loamy texture soil and it might be different in other soil mixtures. Therefore, it is recommended that further experiments can be implemented in various soil textures and furrow lengths to evaluate deficit irrigation management on qualitative and quantitative yield of sugar beet.

Acknowledgments. The research was supported by the Sugar Beet Seed Institute.

\section{REFERENCES}

[1] Akhavan, S., Musavi, S. F., Mostafazadehfard, B., Ghadamifirozabadi, A. (2007): Review on furrow irrigation on yield and water use efficiency of potato farming. Science and Technology of Agriculture and Natural Resources 41(a): 15-26 (in Persian).

[2] Albayrak, M., Gunes, E., Gulcubuk, B. (2010): The effects of irrigation methods on input use and productivities of sugar beet in Central Anatolia, Turkey. - African Journal of Agricultural Research 5(3): 188-195.

[3] Bazza, M., Tayaa, M. (1999): Contribution to Improve Sugar Beet Deficit-Irrigation. - In: Kirda, C., Moutonnet, P, Hera, C., Nielson, D. R. (eds.) Crop Yield Response to Deficit Irrigitation. Kluwer, Dordrecht.

[4] Clover, G. R. G., Jaggard, K. W., Smith, H. G., Azam-Ali, S. N. (2001): The use of radiation interception and transpiration to predict the yield of healthy, drought and virusinfected sugar beet. - Journal of Agricultural Science 136(2): 169-178.

[5] Deng, X. P., Shan, L., Zhang, H., Turner, N. C. (2006): Improving agricultural water use efficiency in arid and semi-arid areas of China. - Agricultural Water Management 80(1): $23-40$.

[6] Doorenbos, J., Kassam, A. H. (1979): Yield response to water. - FAO 33, Rome.

[7] Dunham, R. J., Draycott, A. P., Messem, A. B. (1993): Irrigation of sugar beet in the United Kingdom. - Proceedings of the 56th Congress Institute International de Recherches Betteravieres, Brussels, 25-40. 
[8] EL-Shakawy, A. F., Abdel Maksood, H. H., Mostafa, A. K. (2006): Effect of alternate furrow irrigation and transplanting distance on water utilization efficiency for onion crop. - Misr Journal of Agricultural Engineering 23: 137-150.

[9] Fabeiro, C., Santa Olalla, M., Lopez, R., Dominguez, A. (2003): Production and quality of sugar beet (Beta vulgaris L.) cultivated under controlled deficit irrigation condition in semi-arid climate. - Agric Water Manage 62(3): 215-227.

[10] Firoozabadi, M., Abdollahian-Noghabi, M., Rahimzadeh, F., Moghadam M., Parsaeyan, M. (2003): Effects of different levels of continuous water stress on the yield quality of three sugar beet lines. - Sugar Beet Journal of Iran 19(2): 133-142 (in Persian).

[11] Geraterol, Y. E., Eisenhauer, D. E., Elmore, R. W. (1993): Alternate furrow irrigation for soybean production. - Agricultural Water Management 24: 133-145.

[12] Greets, S., Raes, D. (2009): Deficit irrigation as an pn-farm strategy to maximize crop water productivity in dry area. - Agric Water Manage 96: 1275-1284.

[13] Hardin, L. S. (2008): Revolution. Meetings that changed the world. Bellagio 1969: the Green Revolution. - Nature 455: 470-471.

[14] Hassanli, A. M., Ahmadirad, S. H., Beecham, S. (2010): Evaluation of the influence of irrigation methods and water quality on sugar beet yield and water use efficiency. - Agric Water Manage 97(2): 357-362.

[15] Heerman, D. F. (1985): ET in irrigation management. - Proceedings of the National Conferences in Evapotranspiration, Trans ASAE, 323-334.

[16] Hsiao, T. C. (2000): Leaf and root growth in relation to water status. - Horticultural Science 35(6): 1051-1058.

[17] Ibrahim, M. A. M., Emara, K. (2010): Water saving under alternative furrows surface irrigation in clay soils of north Nile delta. - Fourteenth International Water Technology Conference, Cairo, 21-23 March.

[18] Kirda, C., Moutonnet, P., Hera C., Nielsen D. R. (2000): Crop yield response to deficit irrigation. Kluwer, Dordrecht.

[19] Liang, L. T., Feng, S. Y., Qu, F. T. (2010): Forming mechanism of agricultural non-point source pollution: a theoretical and empirical study. - China Population Resources and Environment 20: 74-80.

[20] Mahmoodi, R., Maralian, H., Aghabarati, A. (2008): Effects of limited irrigation on root yield and quality of sugar beet (Betavulgaris L.). - African Journal of Biotechnology 7(24): 4475-4478.

[21] Maralian, M., Tobeh, A., Seif Amiri, S., Didar-Talesh Mikail, R., Aghabarati, A. (2008): Effects of sowing date and limited irrigation on root yield and quality of sugar beet (Beta vulgaris L.). - Asian J Plant Sci 7(3): 298-303.

[22] Morillo-Velarde, R., Ober, E. S. (2006): Water Use and Irrigation. - In: Draycott, A. P. (ed.): Sugar Beet. Blackwell Publishing, Oxford.

[23] Nelson, D. J., Kaisi, M. M. (2011): Agronomic and economic evaluation of various furrow irrigation strategies for corn production under limited water supply. - Journal of Soil Water Conservation 66(2): 114-120.

[24] Ober, E. S. (2001): The search for drought tolerance in sugar beet. - British Sugar Beet Review 69(1): 40-43.

[25] Ober, E. S., Le Bloa, M., Clark, C. J. A., Royal, A., Jaggard, K. W., Pidgeon, J. D. (2005): Evaluation of physiological traits as indirect selection criteria for drought tolerance in sugar beet. - Field Crops Res 91(2): 231-249.

[26] Pidgeon, J. D., Werker, A. R., Jaggard, K. W., Richter, G. M., Lister, D. H., Jones, P. D. (2001): Climatic impact on the productivity of sugar beet in Europe, 1961-1995. Agricultural and Forest Meteorology 109(1): 27-37.

[27] Rontein, D., Basset, G., Hanson, A. D. (2002): Metabolic engineering of osmoprotectant accumulation in plants. - Metabolic Engineering 4(1): 49-56. 
[28] Rytter, R. M. (2005): water use efficiency, carbon isotope discrimination and biomass production of two sugar beet varieties under well-watered and dry conditions. - Journal of Agronomy and Crop Science 191(13): 426-438.

[29] Sepaskhah, A. R. (1996): Deficit irrigation under alternate furrow irrigation. Proceedings of the Eighth National Committee on Irrigation and Drainage Seminar, Tehran, Iran, pp. 291-304.

[30] Sepaskhah, A. R., Ghasemi, M. M. (2008): Every-other-furrow irrigation with different irrigation intervals for grain sorghum. - Pak J Biol Sci 11(9): 1234-1239.

[31] Sepaskhah, A. R., Parand, A. R. (2006): Effects of alternate furrow irrigation with supplemental every-furrow irrigation at different growth stages on the yield of maize (Zea mays L.). - Plant Production Science 9(4): 415-421.

[32] Shayannejad, M., Moharreri, A. (2009): Effect of every-furrow irrigation on water use efficiency, starch and protein content of potato. - Journal of Agricultural Science 1(2): 107-112.

[33] Tognetti, R., Palladino, M., Minnocci, A., Delfine, S., Alvino, A. (2003): The response of sugar beet to drip and low-pressure sprinkler irrigation in southern Italy. - Agricultural Water Management 60(2): 135-=155.

[34] Topak, R., Sinan, S., Bilal, A. (2011): Effect of different drip irrigation regimes on sugar beet (Beta vulgaris L.) yield, quality and water use efficiency in Middle Anatolian, Turkey. - Irrig Sci 29(1): 79-89.

[35] Uçan, K., Gençoğlan, C. (2004): The effect of water deficit on yield and yield components of sugar beet. - Turk J Agric For 28(3): 163-172.

[36] Vamerali, T., Guarise, M., Ganis, A., Mosca, G. (2009): Effect of water and nitrogen management on fibrous root distribution and turnover in sugar beet. - Eur J Agrom 31: 69-76.

[37] Wang, N., Jin, X., Ye, S. T., Gao, Y. (2016): Optimization of agricultural input efficiency for wheat production in China applying data envelopment analysis method. - Applied Ecology and Environmental Research 15(3): 293-305. 